\title{
Epidermal growth factor improves developmental competence and embryonic quality of singly cultured domestic cat embryos
}

\author{
Chommanart THONGKITTIDILOK'), Theerawat THARASANIT ${ }^{1)}$, Nucharin SONGSASEN ${ }^{2}$, \\ Thanida SANANMUANG ${ }^{3)}$, Sirirak BUARPUNG ${ }^{1)}$ and Mongkol TECHAKUMPHU') \\ 1) Department of Obstetrics, Gynaecology and Reproduction, Faculty of Veterinary Science, Chulalongkorn University, \\ Bangkok 10330, Thailand \\ 2) Smithsonian Conservation Biology Institute, National Zoological Park, Virginia 22630, USA \\ 3) Faculty of Veterinary Medicine, Rajamangala University of Technology, Chonburi, 20110, Thailand
}

\begin{abstract}
This study examined the influence of EGF on the expression of EGF receptors $(E G F R)$ and developmental competence of embryos cultured individually versus those cultured in groups. Cat oocytes were in vitro matured and fertilized (IVM/IVF), and cleaved embryos were randomly assigned to one of seven culture conditions: one group each in which embryos were subjected to group culture supplemented with or without $5 \mathrm{ng} / \mathrm{ml} \mathrm{EGF}$ and five groups in which embryos were subjected to single-embryo culture supplemented with EGF $(0,5,25,50$ or $100 \mathrm{ng} / \mathrm{ml})$. Morulae, blastocysts and hatching blastocysts were assessed at days 5 and 7; post IVF, respectively, and total blastocyst cell numbers were assessed at day 7 . Relative mRNA expressions of EGFR of 2-4-cell embryos, 8-16-cell embryos, morulae and blastocysts cultured in groups or singly with or without EGF supplementation were examined. OCT3/4 and Ki67 in blastocysts derived from the group or single-embryo culture systems with or without EGF supplementation were localized. A higher rate of embryos cultured in groups developed to blastocysts than individually incubated cohorts. Although EGF increased blastocyst formation in the single-embryo culture system, EGF did not affect embryo development in group culture. Expression levels of EGFR decreased in morulae and blastocysts cultured with EGF. An increased ratio of Ki67-positive cells to the total number of cells in the blastocyst was observed in singly cultured embryos in the presence of EGF. However, EGF did not affect the expression of OCT3/4. These findings indicate that EGF enhanced developmental competence of cat embryos cultured singly by stimulating cell proliferation and modulating the EGFR expression at various developmental stages.
\end{abstract}

Key words: Blastocyst, Cat, Epidermal growth factor (EGF), Epidermal growth factor receptor (EGFR), Single-embryo culture

(J. Reprod. Dev. 61: 269-276, 2015)

$\mathbf{T}$ o date, more than half of extant wild felid species are threatened by extinction in their native ranges [1]. Thus, it is important to establish insurance populations of certain species ex situ, a process that can help retain the necessary genetic diversity to ensure species integrity [2]. Within these threatened species collections, there are many genetically valuable females that have never reproduced or have experienced fertility issues as a result of advanced age. To propagate these individuals, efforts have been focused on developing "assisted breeding" technologies originally established in livestock and humans, including in vitro embryo production, to ensure that genetics of all individuals are represented in ex situ populations [3-5]. Thus far, live offspring have been produced after transferring in vitro-derived embryos into recipient females in wild felids species [6-8]. Despite these successes, there are still challenges associated with the limited numbers of good quality oocytes available for in

Received: January 12, 2015

Accepted: March 26, 2015

Published online in J-STAGE: May 17, 2015

C2015 by the Society for Reproduction and Development

Correspondence: M Techakumphu (e-mail: tmongkol@chula.ac.th)

This is an open-access article distributed under the terms of the Creative

Commons Attribution Non-Commercial No Derivatives (by-nc-nd) License

$<$ http://creativecommons.org/licenses/by-nc-nd/3.0/>. vitro embryo production due to old age [9] or poor responses to ovarian stimulation protocols [10].

Thus, it is necessary to culture gametes/embryos individually or in small groups $[11,12]$. However, it has been shown in the mouse and cow that small percentages of embryos cultured singly develop to blastocysts when compared with those incubated in groups (mouse, $49 \%$ vs. $>80 \%$; cow, $2.9 \%$ vs. $30.7 \%$ ) [11, 13]. Furthermore, previous studies have also demonstrated that individually cultured cat [9] and cow embryos [14] fail to reach the compaction stage. To date, several strategies have been established to overcome the poor developmental rate of singly cultured embryos [11]. These include growth factor supplementation, in vitro culture in conditioned medium derived from group-embryo culture and co-culture with autologous cumulus cells $[11,13,15-17]$. Various growth factors such as epidermal growth factor (EGF) and insulin-like growth factor-1 (IGF-1) have been shown to enhance blastocyst development in a single-embryo culture system in the mouse and cow $[13,18,19]$. For the cat, we have recently shown that IGF-1 promotes blastocyst development in a single-embryo culture system by enhancing the expression of its receptor (IGF-1R) [20]. Up to now, there has been no information available on the influence of EGF on the developmental competence of cat embryos either cultured in groups or individually.

Epidermal growth factor is a mitogenic polypeptide that is involved 
in regulating cell proliferation in many cell types, including granulosa cells of preantral follicles [21, 22]. This growth factor also has been shown to promote in vitro maturation (IVM) of mouse, cat, sheep and pig oocytes [23-28]. Addition of EGF to IVM or culture medium promotes cleavage and blastocyst development [13, 29-34]. EGF binds with its receptor $(E G F R)$ and stimulates MAP/ERK and $\mathrm{PI} 3 \mathrm{~K} /$ Akt pathways that, in turn, enhance cell proliferation [22]. It has been shown that EGFR is expressed in the 2-cell to blastocyst stage in the mouse and from the 8-cell stage to the blastocyst stage in humans [35], but it is unknown whether it is expressed in cat embryos. Although the single-embryo culture method has been studied in several species, the quality of blastocysts produced from this has not been clearly identified. It has been suggested that expression of Ki67 and OCT3/4 can be used as markers for blastocyst quality. $\mathrm{Ki67}$ is involved in cell proliferation and is only expressed in the active stage of a cell cycle $[36,37]$. Pluripotency protein, OCT3/4, has been shown to be highly expressed within an inner cell mass of blastocyst stage embryos and is critical for embryogenesis and cell differentiation $[38,39]$.

The objectives of this study were to determine the effects of EGF during in vitro culture (IVC) on (1) developmental competence as well as expressions of pluripotency marker protein (OCT3/4) and proliferation marker protein (Ki67) and (2) the EGFR expression at various developmental stages of cat embryos cultured in a group versus singly. The research hypotheses were (1) that supplementation of a culture environment with EGF would promote embryonic development by stimulating cell proliferation and (2) that EGFR is expressed in cat preimplantation embryos.

\section{Materials and Methods}

All chemicals used in this study were purchased from Sigma Aldrich, St Louis, MO, USA, unless otherwise specified. All animal procedures were performed according to the ethics committees for animal care and use, Faculty of Veterinary Science, Chulalongkorn University (Approval no. 12310048).

\section{Oocyte collection}

Ovaries from routinely ovariohysterectomized mixed-breed domestic cats (Felis catus) at various stages of the estrous cycle were collected from the Veterinary Public Health Division of the Bangkok Metropolitan Administration. The ovaries were maintained and transported at room temperature $(26-30 \mathrm{C})$ in $0.9 \%$ (wt/vol) normal saline containing $100 \mathrm{IU} / \mathrm{ml}$ penicillin and $100 \mu \mathrm{g} / \mathrm{ml}$ streptomycin within $2 \mathrm{~h}$ after surgery. The ovaries were washed twice in the same antibiotic-supplemented saline solution and then placed in a holding medium (HM) (HEPES-buffered M199 supplemented with $1 \mathrm{mM}$ sodium pyruvate, $2 \mathrm{mM}$ L-glutamine, $100 \mathrm{IU} / \mathrm{ml}$ penicillin and 4 $\mathrm{mg} / \mathrm{ml}$ bovine serum albumin [BSA; A3311]). Cumulus oocyte complexes (COCs) were recovered by cutting the surface of the ovaries using a scalpel blade and assessed for morphology under a stereomicroscope at $40 \times$ magnification (SMZ645; Nikon, Tokyo, Japan). Only oocytes with homogeneous dark cytoplasm and fully surrounded by more than five layers of compacted cumulus cells were selected for IVM.

\section{In vitro maturation and in vitro fertilization}

In vitro oocyte maturation (IVM) and in vitro fertilization (IVF) were performed as described previously [40]. For IVM, groups of 25-40 COCs were cultured in $500 \mu \mathrm{l}$ of basic IVM medium ( $\mathrm{NaHCO}_{3}$-M199 with $1.0 \mathrm{mM}$ sodium pyruvate, $2.0 \mathrm{mM} \mathrm{L}$-glutamine, $100 \mathrm{IU} / \mathrm{ml}$ penicillin, $50 \mu \mathrm{g} / \mathrm{ml}$ gentamicin, $4 \mathrm{mg} / \mathrm{ml} \mathrm{BSA)} \mathrm{supple-}$ mented with $0.05 \mathrm{IU} / \mathrm{ml}$ recombinant human follicle-stimulating hormone (rhFSH; Organon, Oss, The Netherlands) and $25 \mathrm{ng} / \mathrm{ml}$ EGF. After 22-24 h of IVM, groups of 10 oocytes were transferred to $50 \mu \mathrm{l}$ droplets of synthetic oviductal fluid (SOF) (containing 6 $\mathrm{mg} / \mathrm{ml} \mathrm{BSA}, 100 \mathrm{IU} / \mathrm{ml}$ penicillin, $50 \mu \mathrm{g} / \mathrm{ml}$ gentamicin). The frozen semen used in this study was collected from ejaculated sperm of one proven-fertility tom cat. Before IVF, the semen was thawed at $37 \mathrm{C}$ for $30 \mathrm{sec}$, and only the sperm samples containing more than $50 \%$ progressive motility were used. The sperm sample was added to the IVF drop to yield a final concentration of $5 \times 10^{5} \mathrm{sperm} / \mathrm{ml}$. The sperm were co-incubated with the COCs for approximately 18 $\mathrm{h}$ at $38.5 \mathrm{C}$ in a humidified atmosphere of $5 \% \mathrm{CO}_{2}$ in air.

\section{In vitro culture}

Presumptive zygotes (day 0 post IVF) that were surrounded by cumulus cells were washed and cultured in $50 \mu \mathrm{l}$ droplets of SOF containing with $4 \mathrm{mg} / \mathrm{ml} \mathrm{BSA}$, and $100 \mathrm{IU} / \mathrm{ml}$ penicillin (IVC-1 medium) for $24 \mathrm{~h}$; after that, all cumulus cells were removed and then assessed for cleavage (i.e., 2-4-cell embryos) on day 2 post IVF (48 h post fertilization). The embryos were transferred to IVC-2 medium (SOF supplemented with the same batch of $10 \% \mathrm{vol} / \mathrm{vol}$ fetal calf serum [FCS], JR Scientific, Woodland, CA, USA) and cultured at $38.5 \mathrm{C}$ in a humidified atmosphere of $5 \% \mathrm{CO}_{2}$ in air for an additional 5 days. Half of the freshly prepared IVC-2 medium was exchanged on day 5 post IVF.

\section{Assessment of embryo development}

The embryos were classified as morulae (having cell compaction without blastocoel formation) on day 5 post IVF, blastocysts (having a fully-expanded blastocoel and two differentiated cell types: inner cell mass and trophectoderm) and hatching blastocysts (hatching of blastocyst cells from zona pellucida) on day 7 post IVF under an inverted microscope at $40 \times$ magnification (CKX41 Olympus, Tokyo, Japan). All blastocysts observed on day 7 were fixed in $4 \%$ (wt/vol) paraformaldehyde overnight and washed twice in phosphate buffered saline (PBS) before permeabilization with $0.1 \%$ Triton $\mathrm{X}-100$ in PBS for $15 \mathrm{~min}$. Blastocysts were incubated with 1:50 goat anti-OCT3/4 polyclonal IgG antibodies (SC8629, Santa Cruz Biotechnology, Santa Cruz, CA, USA) at $37 \mathrm{C}$ for $1 \mathrm{~h}$ and then rinsed in PBS and incubated for $2 \mathrm{~h}$ with 1:50 FITC labeled donkey anti-goat IgG (SC2024, Santa Cruz Biotechnology). After OCT3/4 staining, blastocysts were incubated with 1:50 mouse anti-Ki67 monoclonal antibodies (IS626, Clone MIB-1, DakoCytomation Denmark A/S, Glostrup, Denmark) at $37 \mathrm{C}$ for $1 \mathrm{~h}$; and then rinsed in PBS and incubated for $1 \mathrm{~h}$ with 1:100 TRITC labeled anti-mouse IgG (T5393) to determine the proliferating cells of the blastocyst. Blastocysts were stained with $0.1 \mu \mathrm{g} / \mathrm{ml}$ 4',6-Diamidino-2-phenylindole (DAPI) in PBS at $25 \mathrm{C}$ for $10 \mathrm{~min}$, and total cell numbers were assessed under an epifluorescent microscope (BX51 Olympus). 


\section{RNA extraction}

RNA extraction was performed as previously described [41]. In brief, total RNA was extracted from a group of 20 day 2 embryos (4-8-cell stage), 15 of day 3 embryos (8-16-cell stage), 10 morulae (day 5) and 5 blastocysts (day 7) produced from the same IVF replicate using an Absolutely RNA Nanoprep Kit (Stratagene, San Diego, CA, USA) following the manufacturer's instructions. The purity and quantity of extracted RNA were assessed using a spectrophotometer (NanoDrop ND-2000, Wilmington, DE, USA) and immediately stored at $-80 \mathrm{C}$ until further use. Three replicates were performed in each treatment.

\section{Quantitative RT-PCR ( $q R T-P C R)$}

Reverse transcription (RT) was performed using a First-Strand cDNA Synthesis Kit (SuperScript III Kit, Invitrogen, Carlsbad, CA, USA) according to the manufacturer's instructions. The product was stored at $-20 \mathrm{C}$ until qPCR analysis. The relative expression levels of the target gene $(E G F R)$ were normalized to an endogenous control gene, tyrosine 3-monooxygenase/tryptophan 5-monooxygenase activation protein, zeta polypeptide ( $Y W H A Z$ ), that has previously been shown to be stable during cat preimplantation embryo development [42]: forward primer, 5'GAAGAGTCCTACAAAGACAGCACGC 3', and reverse primer, 5' AATTTTCCCCTCCTTCTCCTGC 3'. The amplicon size of $Y W H A Z$ was $115 \mathrm{bp}$. The EGFR primer was designed from Felis catus EGFR mRNA, complete cds (Accession number: HQ185236.1), using a NCBI primer designing tool (Primer3 software V 0.4.0): forward primer, 5'AGATTGCGAAGGGCATGAAC 3', and reverse primer, 5' GGCGTCTTCACCAGGACATT 3'. The amplicon size of EGFR was $118 \mathrm{bp}$. To confirm the amplified EGFR, the amplicon was extracted using a Gel/PCR DNA Fragments Extraction Kit (Geneaid Biotech, Agoura Hills, CA, USA) and then submitted for sequencing. The sequences subjected to BLAST searches in the NCBI GenBank database to determine the nucleotide identity prior to being used in this study. The EGFR primer designed for this study contained $100 \%$ nucleotide identity with the EGFR mRNA sequence found in Felis catus EGFR mRNA complete cds, HQ185236.1. The qPCR was performed using an Applied Biosystems 7300 Real-Time PCR System (Applied Biosystems, Foster City, CA, USA) with Luminaris Color HiGreen High ROX qPCR Master Mix (Thermo Scientific, Thermo Fisher Scientific, Carlsbad, CA, USA).

Each PCR reaction (total volume of $10 \mu \mathrm{l}$ ) consisted of $2.5 \mu \mathrm{l}$ of DNA mixture, which contained $2 \mu 1$ of reverse transcription product containing either reverse transcriptase $(\mathrm{RT}+$ ) or not containing reverse transcriptase (RT-) as a control, $0.5 \mu 1$ of yellow sample buffer and $7.5 \mu 1$ of a reaction mixture that contained $5 \mu \mathrm{l}$ of Luminaris Color HiGreen High ROX qPCR Master Mix, $0.3 \mu 1$ of both $10 \mu \mathrm{M}$ forward and reverse primers and $1.9 \mu \mathrm{l}$ of nuclease-free water. The thermal cycling conditions were as follows: $2 \mathrm{~min}$ at $50 \mathrm{C}$ for pretreatment of uracil-DNA glycosylase (UDG), $10 \mathrm{~min}$ at $95 \mathrm{C}$ to activate Tag DNA polymerase; and 40 cycles of $15 \mathrm{sec}$ at $95 \mathrm{C}$ for denaturing, $30 \mathrm{sec}$ at $55 \mathrm{C}$ for annealing and $60 \mathrm{sec}$ at $72 \mathrm{C}$ for extension. The relative expression was quantified by Sequence Detection System (SDS) Software Version 1.4 (Applied Biosystems). Day 2 embryos were used as a control group for calculations of relative expression performed by the comparative $\mathrm{Ct}$ method. Data were reported as the relative fold difference in relation to the control group [43].
qPCR products were confirmed by melting curve analysis and run in gel electrophoresis. The qPCR products were analyzed on a $2 \%$ agarose gel (Bio-Rad, Hercules, CA, USA) in $1 \times$ TBE buffer $(90$ $\mathrm{mM}$ Tris, $90 \mathrm{mM}$ boric acid, $2 \mathrm{mM}$ EDTA, pH8) containing $1 \times /$ $\mathrm{ml}$ Redsafe Nucleic Acid Staining Solution (Intron Biotechnology, Gyeonggi-do, Republic of Korea). This was then visualized under UV light (Syngene, Cambridge, UK).

\section{Experimental design}

Experiment 1: Effect of EGF supplementation on developmental competence of embryos cultured singly compared with group-cultured embryos without growth factor supplementation

This experiment determined the effect of EGF supplementation on developmental competence of singly cultured embryos compared with group-cultured embryos without growth factor supplementation. Single embryos at the cleavage stage ( 1 embryo/50 $\mu 1$ droplet) were cultured in IVC-2 medium supplemented with different concentrations of $\operatorname{EGF}(0,5,25,50$, and $100 \mathrm{ng} / \mathrm{ml})$ from day 2 to 7 . Groups of cleaved embryos (10 embryos/50 $\mu$ l droplet) cultured in IVC-2 medium without growth factor supplementation from day 2 to 7 served as a control. The embryos were assessed for morula formation on day 5 and blastocyst formation on day 7 . Three replicates were performed in this experiment.

Experiment 2: Effect of EGF on developmental competence and expressions of EGFR, OCT3/4 and Ki67 of embryos cultured singly or in groups

Experiment 2.1: Effect of EGF on developmental competence of embryos cultured singly or in groups

The results of experiment 1 showed that EGF supplementation even at the lowest dosage $(5 \mathrm{ng} / \mathrm{ml})$ significantly promoted blastocyst formation of singly cultured embryo. This experiment aimed to investigate the effect of EGF $(5 \mathrm{ng} / \mathrm{ml})$ supplementation on developmental competence of either singly or group-cultured embryos. Cleavage stage embryos were cultured individually or in groups in IVC-2 medium with or without $5 \mathrm{ng} / \mathrm{ml}$ EGF supplementation from day 2 to 7 . The control was groups of embryos cultured without EGF supplementation. The embryos were assessed for morula formation on day 5 and blastocyst formation on day 7 . Four replicates were performed in this experiment.

Experiment 2.2: Effect of EGF on EGFR expression of embryos cultured singly or in groups

To evaluate the influence of EGF on EGFR expression at different developmental stages, day 2 embryos (4-8 cells; D2), day 3 embryos (8-16 cells; D3), morula (D5) and blastocyst (D7) stage embryos produced in experiment 2.1 were subjected to qPCR to assess mRNA expression. The relative expressions of 8-16-cell embryos, morulae and blastocysts were calculated based on the $\Delta \mathrm{CT}$ of the control (Day 2 embryos). Three replicates were performed in this experiment.

Experiment 2.3: Effect of EGF on OCT3/4 and Ki67 expression in blastocyst from single and group cultures

To determine the expression of OCT3/4 and Ki67 (a proliferative marker), day 7 blastocysts produced in experiment 2.1 were assessed for OCT3/4- and Ki67-positive cells using immunofluorescent staining. The ratios between the numbers of OCT3/4- and Ki67-positive cells to the total number of cells in each blastocyst were proportionally calculated and compared among the different culture conditions. Forty 
blastocysts per culture treatment were randomly selected and used.

\section{Statistical analysis}

Results were expressed as the mean \pm standard error of the mean (SEM). The percentage of cleavage was calculated relative to the number of oocytes subjected to IVF. Percentages of morulae and day 7 blastocysts were calculated relative to the number of cleaved embryos. Percentage of hatching blastocysts was calculated relative to the total number of blastocysts. Differences between groups in the mean percentage of each developmental stage were assessed by the Chi-squared test. The differences in cell numbers in each group and relative mRNA expression of $E G F R$ were assessed by one-way ANOVA, using the general linear model method. The differences in the ratio between numbers of OCT3/4- and Ki67-positive cells to the total number of cells in each blastocyst among culture conditions were assessed by Kruskal-Wallis test. All statistical analyses were performed using the Statistical Analysis Systems software package (Version 9.0, SAS Institute, Cary, NC, USA). Differences with $\mathrm{P}<0.05$ were considered statistically significant.

\section{Results}

Experiment 1: Effect of EGF supplementation on developmental competence of embryos cultured singly compared with group-cultured embryos without growth factor supplementation

In the absence of EGF, more blastocysts were observed on day 7 in group culture than in the singly cultured group $(\mathrm{P}<0.05$, Table 1). However, culture conditions did not affect the numbers of morulae and hatching blastocysts produced or the total cell number of blastocysts $(\mathrm{P}>0.05)$. Addition of EGF, even at the low dosage of $5 \mathrm{ng} / \mathrm{ml}$, enhanced blastocyst production in the single-embryo culture system to a level comparable $(\mathrm{P}>0.05)$ to group culture (Table 1$)$.

Experiment 2: Effect of EGF on developmental competence and the expressions of EGFR, OCT3/4 and Ki67 in embryos cultured singly or in groups

Experiment 2.1: Effect of EGF on developmental competence of embryos cultured singly or in groups

EGF supplementation did not enhance embryonic development in group culture. However, the percentage of embryos developing to the morula stage was higher in group culture with EGF supplementation than in single-embryo culture $(\mathrm{P}<0.05$, Table 2$)$. EGF enhanced blastocyst development in single-embryo culture to a level comparable to group culture (Table 2). Culture conditions did not affect the number of hatching blastocysts or blastocyst cell numbers.

Experiment 2.2: Effect of EGF on EGFR expression of embryos cultured singly or in groups

When examining the influence of culture conditions on EGFR expression at a given developmental stage, EGF addition as well as culture density (group versus single) did not influence $E G F R$ expression of 8-16-cell embryos (Fig. 1a). However, EGFR transcripts were significantly higher in morula stage embryos cultured singly in the absence of EGF than in morula stage embryos under other culture conditions $(\mathrm{P}<0.05$; Fig. $1 \mathrm{~b}$ ). In blastocysts, EGF significantly decreased $E G F R$ expression in those cultured singly or in groups (Fig. 1c).

Experiment 2.3: The effect of EGF on the ratio of OCT3/4- and Ki67-expressing cells in blastocysts from single and group cultures

Culture conditions did not influence the ratio of OCT3/4-positive cells to the blastocyst total cell numbers under both the single-embryo and group culture conditions. However, EGF increased the ratio of Ki67-positive cells to the blastocyst total cell numbers under the single-embryo culture conditions compared with group culture cohorts (Fig. 2; $\mathrm{P}<0.05$ ). Immunofluorescent staining showed the presence of OCT3/4 protein in nuclei of both ICM and trophectoderm cells with a prominence observed in the ICM (Fig. 3a). Ki67 protein expression was also detected in the nucleolus of both ICM and trophectoderm cells (Fig. 3b).

\section{Discussion}

Culturing a single embryo in a large volume droplet has been shown to impede embryonic development in many mammalian species, including the mouse, cow and cat [13, 41, 44-47]. However, growth factor supplementation can circumvent the adverse effects of low-density embryo culture and thus, enhance embryonic development in vitro $[13,48]$. The present study demonstrates (1) that addition of EGF to a culture medium enhanced the ability of singly cultured embryos to form blastocysts, likely by promoting cell proliferation, and (2) that the EGFR expression level at various developmental stages was influenced by culture density and growth factor supplementation.

During preimplantation development, mammalian embryos undergo cell proliferation, differentiation and apoptosis, all of which are regulated by growth factors secreted from the maternal reproductive tract or embryos themselves [49]. The absence of growth factors or disruption of paracrine/autocrine signaling often results in growth retardation, chromosomal abnormalities, alteration of gene expression, metabolic disruption and increased apoptosis levels [50, 51]. Growth factors exert their effects on preimplantation embryo development by binding to their receptor located within the reproductive tract or an embryo's plasma membrane, which, in turn, stimulates downstream signaling pathways regulating cell proliferation and differentiation [18]. To date, the members of the insulin and insulin-like growth factor (IGF) family, epidermal growth factor (EGF) family, platelet-derived growth factor (PDGF) family and tumor necrosis factor (TNF) family have been shown to regulate embryo development in the cat, mouse, cow, rat, human, pig, sheep and rabbit [20, 49, 52]. EGF has been shown to be involved in blastocyst formation via stimulating protein synthesis, especially in trophectoderm cells $[49,52]$.

Our finding that group embryo culture yielded more blastocysts than single-embryo culture is consistent with previous studies in the cat [9], mouse [2], cow [53] and human [54]. Previous studies have shown that embryo density significantly affects in vitro embryonic development in the cat and others species $[15,41,55,56]$. Specifically, a high embryo density (10 embryos: $12.5 \mu 1$ medium volume; $1: 1.25$ ) often results in fragmentation of cell nuclei and a low blastocyst formation rate due to upregulation of genes regulating stress response (HSP70) or apoptosis (BAX) [56, 57], while a low embryo density (1 embryo, 20-50 $\mu 1$ medium volume) compromises blastocyst formation and reduces the blastocyst cell number $[13,17]$. 
Table 1. Mean percentages ( \pm SEM) of morulae and day 7 blastocysts and numbers of hatching blastocysts and cells in embryo cultured in groups without EGF supplementation and those cultured singly with 0, 5, 25, 50 and $100 \mathrm{ng} / \mathrm{ml} \mathrm{EGF}$

\begin{tabular}{|c|c|c|c|c|c|}
\hline \multirow{2}{*}{ Group } & \multirow{2}{*}{$\begin{array}{c}\text { No. of cleaved } \\
\text { embryos }\end{array}$} & \multicolumn{2}{|c|}{ No. of cleaved embryos developed to } & \multirow{2}{*}{$\begin{array}{l}\text { No. of hatching } \\
\text { blastocysts }\end{array}$} & \multirow{2}{*}{ Cell numbers } \\
\hline & & Morula (\%) & Day 7 blastocyst (\%) & & \\
\hline Group w/o EGF & 65 & $41(63.1 \pm 6.4)$ & $36(55.4 \pm 2.9)^{\mathrm{a}}$ & $14(38.9 \pm 7.2)$ & $155.3 \pm 11.2$ \\
\hline EGF $0 \mathrm{ng} / \mathrm{ml}$ & 55 & $36(65.5 \pm 5.8)$ & $20(36.4 \pm 7.7)^{b}$ & $5(25.0 \pm 11.4)$ & $146.3 \pm 9.3$ \\
\hline EGF $5 \mathrm{ng} / \mathrm{ml}$ & 57 & $37(64.9 \pm 6.4)$ & $32(56.1 \pm 6.6)^{\mathrm{a}}$ & $14(43.8 \pm 16.0)$ & $186.7 \pm 9.1$ \\
\hline EGF $25 \mathrm{ng} / \mathrm{ml}$ & 61 & $35(57.4 \pm 6.4)$ & $26(42.6 \pm 6.4)^{\mathrm{a}}$ & $9(34.6 \pm 10.0)$ & $161.4 \pm 10.2$ \\
\hline EGF $50 \mathrm{ng} / \mathrm{ml}$ & 58 & $33(56.9 \pm 6.6)$ & $30(51.7 \pm 6.6)^{\mathrm{a}}$ & $13(43.3 \pm 6.2)$ & $188.0 \pm 12.7$ \\
\hline $\mathrm{EGF} 100 \mathrm{ng} / \mathrm{ml}$ & 66 & $45(68.2 \pm 5.8)$ & $36(54.5 \pm 6.2)^{\mathrm{a}}$ & $13(36.1 \pm 5.6)$ & $166.6 \pm 17.1$ \\
\hline
\end{tabular}

a,b Within a column, different superscripts denote values that differ significantly $(\mathrm{P} \leq 0.05)$. w/o, without.

Table 2. Mean percentages ( \pm SEM) of morulae and day 7 blastocysts and numbers of hatching blastocysts and cells in embryo cultured in groups and singly without or with $5 \mathrm{ng} / \mathrm{ml}$ EGF supplementation

\begin{tabular}{|c|c|c|c|c|c|}
\hline \multirow{2}{*}{ Group } & \multirow{2}{*}{$\begin{array}{c}\text { No. of cleaved } \\
\text { embryos }\end{array}$} & \multicolumn{2}{|c|}{ No. of cleaved embryos developed to } & \multirow{2}{*}{$\begin{array}{c}\text { No. of hatching } \\
\text { blastocysts }\end{array}$} & \multirow{2}{*}{ Cell number: } \\
\hline & & Morula (\%) & Day 7 blastocyst (\%) & & \\
\hline Group w/o EGF & 90 & $73(81.1 \pm 4.3)^{\mathrm{ab}}$ & $65(72.2 \pm 3.8)^{\mathrm{a}}$ & $40(61.5 \pm 6.7)$ & $157.6 \pm 10.2$ \\
\hline Group + EGF $5 \mathrm{ng} / \mathrm{ml}$ & 90 & $79(87.8 \pm 7.1)^{\mathrm{a}}$ & $58(64.4 \pm 4.1)^{\mathrm{a}}$ & $32(55.2 \pm 5.1)$ & $160.4 \pm 11.5$ \\
\hline Single w/o EGF & 88 & $66(75.0 \pm 5.7)^{\mathrm{b}}$ & $41(46.6 \pm 2.4)^{b}$ & $24(58.5 \pm 6.1)$ & $172.9 \pm 12.0$ \\
\hline Single + EGF $5 \mathrm{ng} / \mathrm{ml}$ & 86 & $63(73.3 \pm 4.2)^{b}$ & $55(64.1 \pm 8.0)^{\mathrm{a}}$ & $33(60.0 \pm 8.0)$ & $160.0 \pm 11.0$ \\
\hline
\end{tabular}

${ }_{\mathrm{a}, \mathrm{b}}$ Within a column, different superscripts denote values that differ significantly $(\mathrm{P} \leq 0.05)$. w/o, without.

(a)

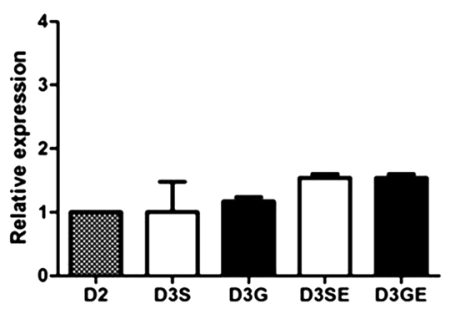

(b)

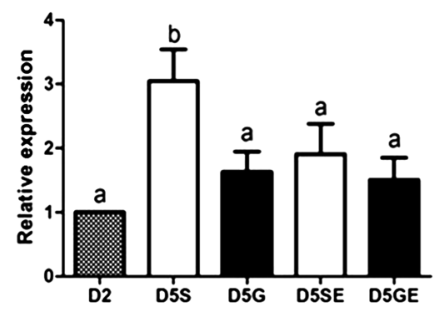

(c)

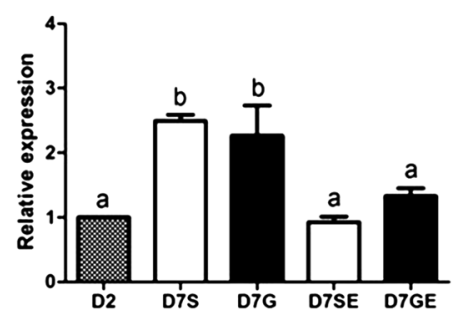

Fig. 1. (a) Relative expression (mean \pm SEM) of EGFR transcript in 8-16-cell embryos on day 3 cultured either singly or in groups without (D3S, D3G) or with EGF supplementation (D3SE, D3GE). (b) Relative expression (mean \pm SEM) of EGFR transcript in morulae on day 5 cultured either singly or in groups without (D5S, D5G) or with EGF supplementation (D5SE, D5GE). (c) Relative expression (mean \pm SEM) of EGFR transcript in blastocysts on day 7 cultured either singly or in groups without (D7S, D7G) or with EGF supplementation (D7SE, D7GE). Relative expression analyzed using real-time PCR with YWHAZ used to normalize each gene, and 4-8-cell embryos (D2) used as calibrators. ${ }^{\mathrm{a}, \mathrm{b}}$ Different letters on bars indicate values that differ significantly $(\mathrm{P}<0.05)$.
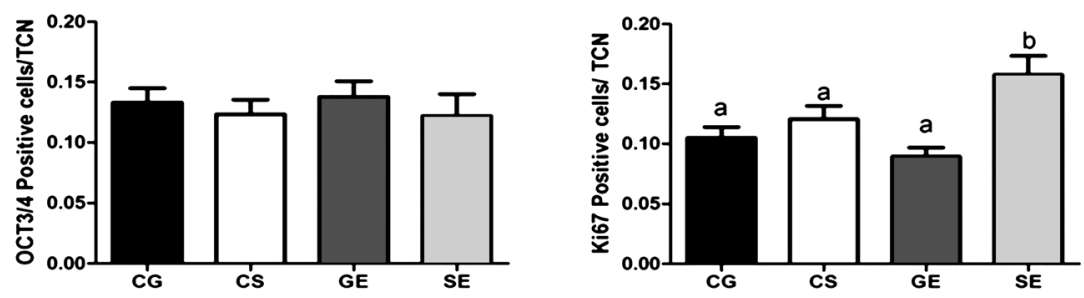

Fig. 2. Ratios of OCT3/4- and Ki67-positive cells to total cell number (TCN) among blastocysts derived from embryos cultured singly and in groups without (CS or CG respectively) or with $5 \mathrm{ng} / \mathrm{ml}$ EGF supplementation (SE or GE, respectively). ${ }^{\mathrm{a}, \mathrm{b}}$ Different letters on bars indicate values that differ significantly $(\mathrm{P}<0.05)$. 

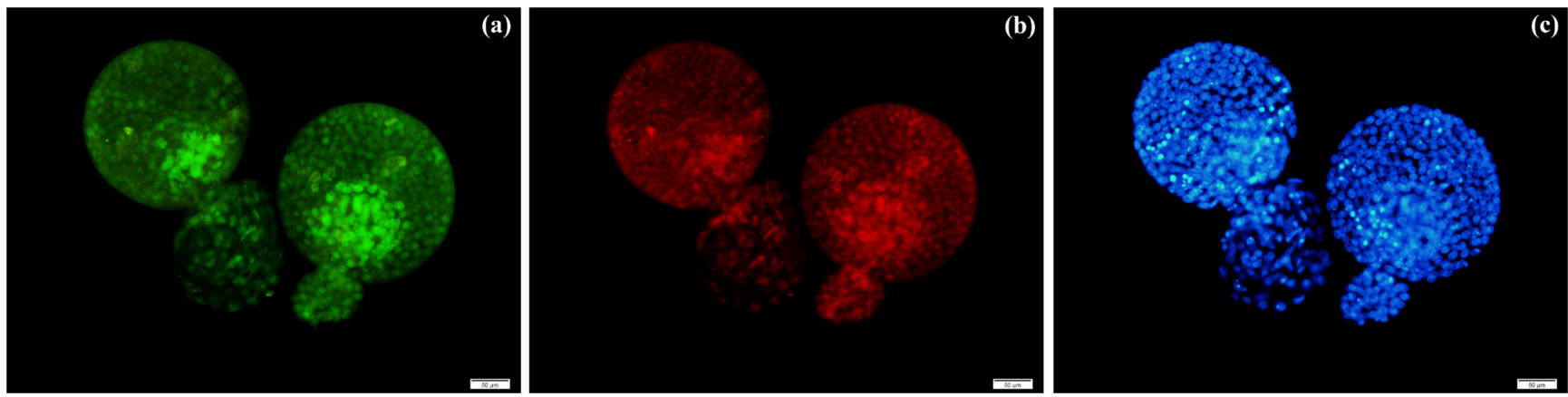

Fig. 3. Immunofluorescent staining of blastocysts for OCT3/4 (a) and Ki67 (b). DAPI staining to show blastomere nuclei (c). Bar $=50 \mu \mathrm{m}$.

Generally, optimal embryonic development can be obtained when the embryo density is one embryo per 5-10 $\mu 1$ [57, 58]. Culturing single human embryos in small droplets (individual culture in 20 $\mu \mathrm{l}$ droplets or in ultramicrodroplets [1.5 to $2 \mu \mathrm{l}]$ ) yielded a higher number of blastomeres, and the implantation or even pregnancy rate were comparable to those of embryos cultured in $50 \mu 1$ droplets [2]. It has been postulated that an increased embryo density improves blastocyst development by facilitating localization of growth factors, nutrients and beneficial metabolites while limiting diffusion of these embryotrophic substances away from the embryos [59]. Future studies on the effect of culturing individual embryos in droplets with a small volume on cat embryonic development are warranted.

Several studies have demonstrated that growth factors enhance blastocyst formation in the group cultured system by decreasing the rate of apoptosis and enhancing cell proliferation and protein synthesis $[19,32,60,61]$. Specifically, supplementation of EGF at $5 \mathrm{ng} / \mathrm{ml}$ from $18 \mathrm{~h}$ post insemination to $192 \mathrm{~h}$ post insemination increased the percentage of bovine blastocysts in group culture (20 embryos/50 $\mu$ l) compared with an unsupplemented group [32]. In contrast, our study found that supplementation of EGF in the group cultured system did not promote blastocyst formation. This discrepancy may be due to a species-specific response to EGF (cat versus cow) or the differences in embryo density (10 embryos in 50 $\mu 1$ versus 20 embryos in $50 \mu 1$ ) between the two studies.

It has been suggested that when embryos are cultured individually, most embryo-derived autocrine growth factors are diluted in this system $[13,19]$. Growth factor supplementation could at least compensate for the low concentration of growth factors under these culture conditions $[13,19]$. EGF was considered one of the autocrine growth factors produced from human preimplantation embryos at the 8-cell and blastocyst stage [62]. Our study found that addition of EGF even at a low concentration $(5 \mathrm{ng} / \mathrm{ml})$ enhanced blastocyst development to the same level as the group culture control. It should be noted that fetal bovine serum was present in the culture medium used in this study. The addition of serum to the culture medium was due to the limited ability of simple media to support embryo development in the absence of serum [63]. While it is known that serum contains several unknown factors that can promote or inhibit embryonic development [63], this protein supplement was added to all culture treatments, including the no EGF control. Thus, the increased blastocyst development in the embryos cultured singly in the presence of EGF was likely due to the beneficial effect of this growth factor.

This study also found that $E G F R$ was expressed throughout the cat preimplantation developmental stages (4-8-cell embryos, 8-16-cell embryos, morulae and blastocysts) under both the group and single-embryo culture conditions. The influence of EGF on $E G F R$ expression was assessed and found to decrease the expression of EGFR transcript in morulae cultured singly and blastocysts cultured either individually or in groups. This finding is contrary to that of a previous study in which EGF supplementation at 0.1 $\mathrm{ng} / \mathrm{ml}$ significantly increased $E G F R$ expression in preimplantation mouse embryos compared with the control and groups treated with higher concentrations of EGF (1, 10 and $100 \mathrm{ng} / \mathrm{ml})$. Furthermore, in that study, EGFR expression tended to decrease as the EGF dosage increased [64]. Therefore, the inconsistency between our study and the previous finding may be due to the different concentrations of EGF $(0.1 \mathrm{ng} / \mathrm{ml} v s .25 \mathrm{ng} / \mathrm{ml})$ or species differences. It has been previously shown in a pleochromocytoma of the rat adrenal medulla cell line (PC12 cells) and human squamous carcinoma cell line (A431) that after binding to its ligand and internalization, EGFR either recycles back to the cell surface or is transported to endosomes/ lysosomes for degradation $[65,66]$. Addition of EGF to a culture medium may result in excessive binding of EGFR and its ligand that leads to the reduction of EGFR on the cell surface. Nevertheless, the downregulation of EGFR observed in the present study did not result in decreased embryonic development, as EGF increased morula development in group culture and blastocyst formation in embryos cultured singly. To date, the exact mechanisms by which EGF stimulates blastocyst formation of embryos cultured singly have not been determined. Our study found that EGF supplementation significantly increased the proportion of Ki67-positive cells within blastocysts derived from individual embryo culture, although the total cell numbers proportions of OCT3/4-positive cells did not differ. This suggests that the EGF supplementation exerted a positive effect on the proliferative activity of the blastocysts, as Ki67 is considered a marker of cell proliferation in only active stages of the cell cycle (G1, S, G2 and M) in mouse embryos [36, 37]. Previous studies demonstrated that EGF stimulated entry of rat hepatocytes into the $\mathrm{S}$ phase [67] and the proliferative fraction ( $\mathrm{S}$ and G2/M phase) in a normal human breast epithelial cell line (MCF10A) [68]. However, the progression of the cell cycle from the $\mathrm{G} 2$ to $\mathrm{M}$ phase required 
the activation of EGFR $[68,69]$, but we did not find upregulation of EGFR in blastocysts. Thus, the beneficial effect of EGF on singly cultured cat embryos observed in the present study is likely, in part, due to the progression of the cell cycle (from the G1 to G2 phase). Future studies that involve incubating cat embryos with EGF and specific inhibitors of EGFR or MAPK will confirm this hypothesis.

In conclusion, these research findings demonstrated that EGF plays an important role in cat embryo development. Furthermore, the findings show that EGF-enhanced development of domestic cat embryos cultured singly can be extrapolated to improve the developmental potential of wild felid embryos, especially when the numbers of high-quality oocytes are limited.

\section{Acknowledgements}

C Thongkittidilok is the recipient of a grant from the Royal Golden Jubilee Ph.D. Program (PHD0032/2553), Thailand Research Fund (TRF). This research was financially supported by the $90^{\text {th }}$ Anniversary of Chulalongkorn University Fund and TRFRSA5680028. Finally, the authors would like to thank the Veterinary Public Health Division of the Bangkok Metropolitan Administration, Thailand, for sample collection.

\section{References}

1. IUCN International Union for Conservation of Nature and Natural Resource. IUCN Red List of Threatened Species 2014. http://www.redlist.org.

2. Ali J. Continuous ultra micro-drop culture yields higher pregnancy and implantation rates than either large-drop culture or fresh-medium replacement. Clin Embryol 2004; 7: 17-23. (online).

3. Comizzoli P, Songsasen N, Wildt DE. Protecting and extending fertility for females of wild and endangered mammals. Cancer Treat Res 2010; 156: 87-100. [Medline] [CrossRef]

4. Pukazhenthi BS, Wildt DE. Which reproductive technologies are most relevant to studying, managing and conserving wildlife? Reprod Fertil Dev 2004; 16: 33-46. [Medline] [CrossRef]

5. Wildt DE, Swanson W, Brown J, Sliwa A, Vargas A. Felids ex situ: managed programs, research and species recovery. In: Macdonald D, Loveridge AJ (eds.), The Biology and Conservation of Wild Felids. New York: Oxford University Press; 2010: 217-236.

6. Pope CE. Embryo technology in conservation efforts for endangered felids. Theriogenology 2000; 53: 163-174. [Medline] [CrossRef]

7. Pope CE, Gómez MC, Kagawa N, Kuwayama M, Leibo SP, Dresser BL. In vivo survival of domestic cat oocytes after vitrification, intracytoplasmic sperm injection and embryo transfer. Theriogenology 2012; 77: 531-538. [Medline] [CrossRef]

8. Swanson WF. Laparoscopic oviductal embryo transfer and artificial insemination in felids—challenges, strategies and successes. Reprod Domest Anim 2012; 47(Suppl 6): 136-140. [Medline] [CrossRef]

9. Spindler RE, Wildt DE. Quality and age of companion felid embryos modulate enhanced development by group culture. Biol Reprod 2002; 66: 167-173. [Medline] [CrossRef]

10. Pelican KM, Wildt DE, Pukazhenthi B, Howard J. Ovarian control for assisted reproduction in the domestic cat and wild felids. Theriogenology 2006; 66: 37-48. [Medline] [CrossRef]

11. Goovaerts IG, Leroy JL, Van Soom A, De Clercq JB, Andries S, Bols PE. Effect of cumulus cell coculture and oxygen tension on the in vitro developmental competence of bovine zygotes cultured singly. Theriogenology 2009; 71: 729-738. [Medline] [CrossRef]

12. Vajta G, Korösi T, Du Y, Nakata K, Ieda S, Kuwayama M, Nagy ZP. The Well-ofthe-Well system: an efficient approach to improve embryo development. Reprod Biomed Online 2008; 17: 73-81. [Medline] [CrossRef]

13. Paria BC, Dey SK. Preimplantation embryo development in vitro: cooperative interactions among embryos and role of growth factors. Proc Natl Acad Sci USA 1990; 87: 4756-4760. [Medline] [CrossRef]

14. Carolan $\mathbf{C}$, Lonergan $\mathbf{P}$, Khatir $\mathbf{H}$, Mermillod $\mathbf{P}$. In vitro production of bovine embryos using individual oocytes. Mol Reprod Dev 1996; 45: 145-150. [Medline] [CrossRef]

15. Fujita T, Umeki H, Shimura H, Kugumiya K, Shiga K. Effect of group culture and embryo-culture conditioned medium on development of bovine embryos. $J$ Reprod Dev 2006; 52: 137-142. [Medline] [CrossRef]

16. Goovaerts IG, Leroy JL, Jorssen EP, Bols PE. Noninvasive bovine oocyte quality assessment: possibilities of a single oocyte culture. Theriogenology 2010; 74: 1509-1520. [Medline] [CrossRef]

17. Goovaerts IG, Leroy JL, Rizos D, Bermejo-Alvarez P, Gutierrez-Adan A, Jorssen EP, Bols PE. Single in vitro bovine embryo production: coculture with autologous cumulus cells, developmental competence, embryo quality and gene expression profiles. Theriogenology 2011; 76: 1293-1303. [Medline] [CrossRef]

18. Lim JM, Hansel W. Roles of growth factors in the development of bovine embryos fertilized in vitro and cultured singly in a defined medium. Reprod Fertil Dev 1996; 8: 1199-1205. [Medline] [CrossRef]

19. O'Neill C. Evidence for the requirement of autocrine growth factors for development of mouse preimplantation embryos in vitro. Biol Reprod 1997; 56: 229-237. [Medline] [CrossRef]

20. Thongkittidilok C, Tharasanit T, Sananmuang T, Buarpung S, Techakumphu M Insulin-like growth factor-1 (IGF-1) enhances developmental competence of cat embryos cultured singly by modulating the expression of its receptor (IGF-1R) and reducing developmental block. Growth Horm IGF Res 2014; 24: 76-82. [Medline] [CrossRef]

21. Gospodarowicz D, Bialecki H. Fibroblast and epidermal growth factors are mitogenic agents for cultured granulosa cells of rodent, porcine, and human origin. Endocrinology 1979; 104: 757-764. [Medline] [CrossRef]

22. Fujihara M, Comizzoli P, Keefer CL, Wildt DE, Songsasen N. Epidermal growth factor (EGF) sustains in vitro primordial follicle viability by enhancing stromal cell proliferation via MAPK and PI3K pathways in the prepubertal, but not adult, cat ovary. Biol Reprod 2014; 90: 86. [Medline] [CrossRef]

23. Conti M, Hsieh M, Park JY, Su YQ. Role of the epidermal growth factor network in ovarian follicles. Mol Endocrinol 2006; 20: 715-723. [Medline] [CrossRef]

24. Demeestere I, Centner J, Gervy C, Englert Y, Delbaere A. Impact of various endocrine and paracrine factors on in vitro culture of preantral follicles in rodents. Reproduction 2005; 130: 147-156. [Medline] [CrossRef]

25. Merlo B, Iacono E, Zambelli D, Prati F, Belluzzi S. Effect of EGF on in vitro maturation of domestic cat oocytes. Theriogenology 2005; 63: 2032-2039. [Medline] [CrossRef]

26. Peng $\mathbf{X}$, Yang $\mathbf{M}$, Wang $\mathbf{L}$, Tong $\mathbf{C}$, Guo $\mathbf{Z}$. In vitro culture of sheep lamb ovarian cortical tissue in a sequential culture medium. J Assist Reprod Genet 2010; 27: 247-257. [Medline] [CrossRef]

27. Procházka R, Petlach M, Nagyová E, Nemcová L. Effect of epidermal growth factorlike peptides on pig cumulus cell expansion, oocyte maturation, and acquisition of developmental competence in vitro: comparison with gonadotropins. Reproduction 2011; 141 425-435. [Medline] [CrossRef]

28. Lorenzo PL, Illera MJ, Illera JC, Illera M. Enhancement of cumulus expansion and nuclear maturation during bovine oocyte maturation in vitro by the addition of epidermal growth factor and insulin-like growth factor I. J Reprod Fertil 1994; 101: 697-701. [Medline] [CrossRef]

29. Chandra V, Misha A, Taru SG. Effect of growth factors (epidermal growth factor, platelet derived growth factor, and insulin-like growth factor-1) on buffalo (Bubalus bubalis) embryos produced in vitro. Indian J Anim Sci 2012; 82: 1510-1514.

30. Neira JA, Tainturier D, Peña MA, Martal J. Effect of the association of IGF-I, IGF-II, bFGF, TGF- $\beta 1$, GM-CSF, and LIF on the development of bovine embryos produced in vitro. Theriogenology 2010; 73: 595-604. [Medline] [CrossRef]

31. Shabankareh HK, Zandi M. Developmental potential of sheep oocytes cultured in different maturation media: effects of epidermal growth factor, insulin-like growth factor I, and cysteamine. Fertil Steril 2010; 94: 335-340. [Medline] [CrossRef]

32. Sirisathien S, Hernandez-Fonseca HJ, Brackett BG. Influences of epidermal growth factor and insulin-like growth factor-I on bovine blastocyst development in vitro. Anim Reprod Sci 2003; 77: 21-32. [Medline] [CrossRef]

33. Song HJ, Kang EJ, Maeng GH, Ock SA, Lee SL, Yoo JG, Jeon BG, Rho GJ. Influence of epidermal growth factor supplementation during in vitro maturation on nuclea status and gene expression of canine oocytes. Res Vet Sci 2011; 91: 439-445. [Medline] [CrossRef]

34. Lee ES, Fukui Y. Effect of various growth factors in a defined culture medium on in vitro development of bovine embryos matured and fertilized in vitro. Theriogenology 1995; 44: 71-83. [CrossRef]

35. Kane MT, Morgan PM, Coonan C. Peptide growth factors and preimplantation development. Hum Reprod Update 1997; 3: 137-157. [Medline] [CrossRef]

36. Oh S, Lee D, Kim T, Kim TS, Oh HJ, Hwang CY, Kong YY, Kwon KS, Lim DS. Crucial role for Mst1 and Mst2 kinases in early embryonic development of the mouse. Mol Cell Biol 2009; 29: 6309-6320. [Medline] [CrossRef]

37. Winking H, Gerdes J, Traut W. Expression of the proliferation marker Ki-67 during early mouse development. Cytogenet Genome Res 2004; 105: 251-256. [Medline] [CrossRef]

38. Pesce M, Wang X, Wolgemuth DJ, Schöler H. Differential expression of the Oct-4 
transcription factor during mouse germ cell differentiation. Mech Dev 1998; 71: 89-98. [Medline] [CrossRef]

39. Wu G, Schöler HR. Role of Oct4 in the early embryo development. Cell Regen (Lond) 2014; 3: 7. [Medline] [CrossRef]

40. Tharasanit T, Thongkittidilok C, Sananmuang T, Techakumphu M. Recombinant human follicle stimulating hormone and growth factors improve the meiotic and developmental competence of cat oocytes. Thai J Vet Med 2014; 44: 107-115.

41. Sananmuang T, Tharasanit T, Nguyen C, Phutikanit N, Techakumphu M. Culture medium and embryo density influence on developmental competence and gene expression of cat embryos. Theriogenology 2011; 75: 1708-1719. [Medline] [CrossRef]

42. Filliers M, Goossens K, Van Soom A, Merlo B, Pope CE, de Rooster H, Smits K, Vandaele L, Peelman LJ. Gene expression profiling of pluripotency and differentiationrelated markers in cat oocytes and preimplantation embryos. Reprod Fertil Dev 2012; 24: 691-703. [Medline] [CrossRef]

43. Livak KJ, Schmittgen TD. Analysis of relative gene expression data using real-time quantitative PCR and the 2(-Delta Delta C(T)) Method. Methods 2001; 25: 402-408. [Medline] [CrossRef]

44. Donnay I, Van Langendonckt A, Auquier P, Grisart B, Vansteenbrugge A, Massip A, Dessy F. Effects of co-culture and embryo number on the in vitro development of bovine embryos. Theriogenology 1997; 47: 1549-1561. [Medline] [CrossRef]

45. Keefer CL, Stice SL, Paprocki AM, Golueke P. In vitro culture of bovine IVM-IVF embryos: Cooperative interaction among embryos and the role of growth factors. Theriogenology 1994; 41: 1323-1331. [Medline] [CrossRef]

46. Lane M, Gardner DK. Effect of incubation volume and embryo density on the development and viability of mouse embryos in vitro. Hum Reprod 1992; 7: 558-562. [Medline]

47. Pereira DC, Dode MA, Rumpf R. Evaluation of different culture systems on the in vitro production of bovine embryos. Theriogenology 2005; 63: 1131-1141. [Medline] [CrossRef]

48. Cebrian-Serrano A, Salvador I, Silvestre MA. Beneficial effect of two culture systems with small groups of embryos on the development and quality of in vitro-produced bovine embryos. Anat Histol Embryol 2014; 43: 22-30. [Medline] [CrossRef]

49. Hardy K, Spanos S. Growth factor expression and function in the human and mouse preimplantation embryo. J Endocrinol 2002; 172: 221-236. [Medline] [CrossRef]

50. Gopichandran N, Leese HJ. The effect of paracrine/autocrine interactions on the in vitro culture of bovine preimplantation embryos. Reproduction 2006; 131: 269-277. [Medline] [CrossRef]

51. Riedemann J, Takiguchi M, Sohail M, Macaulay VM. The EGF receptor interacts with the type 1 IGF receptor and regulates its stability. Biochem Biophys Res Commun 2007; 355: 707-714. [Medline] [CrossRef]

52. Richter KS. The importance of growth factors for preimplantation embryo development and in-vitro culture. Curr Opin Obstet Gynecol 2008; 20: 292-304. [Medline] [CrossRef]

53. O'Doherty EM, Wade MG, Hill JL, Boland MP. Effects of culturing bovine oocytes either singly or in groups on development to blastocysts. Theriogenology 1997; 48: 161-169. [Medline] [CrossRef]

54. Moessner J, Dodson WC. The quality of human embryo growth is improved when embryos are cultured in groups rather than separately. Fertil Steril 1995; 64: 1034-1035. [Medline]

55. Dai SJ, Xu CL, Wang J, Sun YP, Chian RC. Effect of culture medium volume and embryo density on early mouse embryonic development: tracking the development of the individual embryo. J Assist Reprod Genet 2012; 29: 617-623. [Medline] [CrossRef]

56. de Oliveira ATD, Lopes RFF, Rodrigues JL. Gene expression and developmental competence of bovine embryos produced in vitro under varying embryo density conditions Theriogenology 2005; 64: 1559-1572. [Medline] [CrossRef]

57. Sananmuang T, Phutikanit N, Nguyen C, Manee-In S, Techakumphu M, Tharasanit T. In vitro culture of feline embryos increases stress-induced heat shock protein 70 and apoptotic related genes. J Reprod Dev 2013; 59: 180-188. [Medline] [CrossRef]

58. Vutyavanich T, Saeng-Anan U, Sirisukkasem S, Piromlertamorn W. Effect of embryo density and microdrop volume on the blastocyst development of mouse two-cell embryos. Fertil Steril 2011; 95: 1435-1439. [Medline] [CrossRef]

59. Reed ML. Culture systems: embryo density. Methods Mol Biol 2012; 912: 273-312. [Medline]

60. Ahumada CJ, Salvador I, Cebrian-Serrano A, Lopera R, Silvestre MA. Effect of supplementation of different growth factors in embryo culture medium with a small number of bovine embryos on in vitro embryo development and quality. Animal 2013; 7 : 455-462. [Medline] [CrossRef]

61. Block J, Wrenzycki C, Niemann H, Herrmann D, Hansen PJ. Effects of insulin-like growth factor- 1 on cellular and molecular characteristics of bovine blastocysts produced in vitro. Mol Reprod Dev 2008; 75: 895-903. [Medline] [CrossRef]

62. Chia CM, Winston RML, Handyside AH. EGF, TGF- $\alpha$ and EGFR expression in human preimplantation embryos. Development 1995; 121: 299-307. [Medline]

63. Gardner DK, Lane M. Embryo culture systems. In: Gardner DK (eds.), In Vitro Fertilization: A Practical Approach. New York: Informa Healthcare; 2007: 221-264.

64. Kim CH, Chae HD, Cheon YP, Kang BM, Chang YS, Mok JE. The effect of epiderma growth factor on the preimplantation development, implantation and its receptor expression in mouse embryos. J Obstet Gynaecol Res 1999; 25: 87-93. [Medline] [CrossRef]

65. Chen W, Martindale JL, Holbrook NJ, Liu Y. Tumor promoter arsenite activates extracellular signal-regulated kinase through a signaling pathway mediated by epidermal growth factor receptor and Shc. Mol Cell Biol 1998; 18: 5178-5188. [Medline]

66. Masui H, Castro L, Mendelsohn J. Consumption of EGF by A431 cells: evidence for receptor recycling. J Cell Biol 1993; 120: 85-93. [Medline] [CrossRef]

67. Luo Y, Dixon CJ, Hall JF, White PJ, Boarder MR. A role for Akt in epidermal growth factor-stimulated cell cycle progression in cultured hepatocytes: generation of a hyperproliferative window after adenoviral expression of constitutively active Akt. J Pharmacol Exp Ther 2007; 321: 884-891. [Medline] [CrossRef]

68. LeVea CM, Reeder JE, Mooney RA. EGF-dependent cell cycle progression is controlled by density-dependent regulation of Akt activation. Exp Cell Res 2004; 297: 272-284. [Medline] [CrossRef]

69. Baker NE, Yu SY. The EGF receptor defines domains of cell cycle progression and survival to regulate cell number in the developing Drosophila eye. Cell 2001; 104: 699-708. [Medline] [CrossRef] 